\title{
DIFFERENTIAL ACTIVATION OF DIBUTYRYL cAMP-DIFFERENTIATED HL-60 HUMAN LEUKEMIA CELLS BY CHEMOATTRACTANTS
}

\author{
JAN F. KLINKER, INGO SCHWANER, STEFAN OFFERMANNS, \\ ASTRID HAGELÜKEN and ROLAND SEIFERT* \\ Institut für Pharmakologie, Freie Universität Berlin, Thielallee 69-73, D-14195 Berlin, Germany
}

(Received 7 June 1994; accepted 22 August 1994)

\begin{abstract}
Dibutyryl cAMP-differentiated HL-60 human leukemia cells possess receptors for the chemoattractants $N$-formyl-L-methionyl-L-leucyl-L-phenylalanine (fMLP), C5a and leukotriene $\mathrm{B}_{4}$ $\left(\mathrm{LTB}_{4}\right)$. We compared the effects of these chemoattractants in HL-60 membranes and in intact HL-60 cells. fMLP, C5a and $\mathrm{LTB}_{4}$ stimulated GTP hydrolysis and guanosine 5'-O-[3-thio]triphosphate (GTP $[\gamma$ S ]) binding in HL-60 membranes with similar effectiveness and in a pertussis toxin (PTX)sensitive manner. They also stimulated photolabeling of the $\alpha$-subunits of the guanine nucleotidebinding proteins ( $G$-proteins), $G_{i 2}$ and $G_{i 3}$ with similar effectiveness. Chloride salts of monovalent cations differentially enhanced and inhibited chemoattractant-induced GTP hydrolyses. C5a was less effective than $\mathrm{FMLP}$ in enhancing cholera toxin-catalysed ADP-ribosylation of $\mathrm{G}_{\mathrm{i} \alpha 2}$ and $G_{\mathrm{i \alpha} 3}$, and $\mathrm{LTB}_{4}$ was ineffective. fMLP was more effective than $\mathrm{C}^{2} \mathrm{a}$ and $\mathrm{LTB}_{4}$ in stimulating $\mathrm{Ca}^{2+}$ influx in $\mathrm{HL}-60$ cells. C5a- and $\mathrm{LTB}_{4}$-induced rises in cytosolic $\mathrm{Ca}^{2+}$ concentration $\left(\left[\mathrm{Ca}^{2+}\right]_{i}\right)$ were PTX-sensitive, whereas the effect of fMLP was partially PTX-insensitive. $\mathrm{LTB}_{4}$-induced rises in $\left[\mathrm{Ca}^{2+}\right]_{i}$ were more sensitive towards homologous desensitization than those induced by C5a, and the effect of fMLP was resistant in this regard. C5a was considerably less effective than $\mathrm{MLP}$ in activating superoxide anion formation and azurophilic granule release, and $\mathrm{LTB}_{4}$ was ineffective. Our data suggest that fMLP, C5a and $\mathrm{LTB}_{4}$ effectively activate the G-proteins, $G_{i 2}$ and $G_{i 3}$, in HL-60 cells and that fMLP may additionally activate PTX-insensitive G-proteins. fMLP, C5a and $\mathrm{LTB}_{4}$ are full, partial and incomplete secretagogues, respectively, and these differences may be due to differences in homologous receptor desensitization and qualitative $\mathrm{G}_{\mathrm{i}}$-protein activation.
\end{abstract}

Key words: HL-60 cells; formyl peptides; complement C5a; leukotriene $\mathrm{B}_{4}$; chemoattractant receptors; $\mathrm{G}_{\text {i-proteins }}$

Human neutrophils and differentiated HL-60 human leukemia cells possess receptors for the chemoattractants fMLP, $\dagger$ complement C5a and $\mathrm{LTB}_{4}$ $[1,2]$. Principally, these chemoattractants activate similar signal transduction processes. Specifically, the occupation of chemoattractant receptors with agonists results in the activation of PTX-sensitive guanine nucleotide-binding proteins ( $G$-proteins) of the $G_{i}$-family with the subsequent stimulation of phospholipase C [EC 3.1.4.10] [1,2]. Subsequently, $\mathrm{Ca}^{2+}$ is mobilized from intracellular stores and $\mathrm{Ca}^{2+}$ also enters the cytosol through non-selective cation channels $[1,2]$. Activation of the $\mathrm{Ca}^{2+}$ influx is required for stimulation of the superoxide anion $\left(\mathrm{O}_{2}^{-}\right)$-forming NADPH oxidase [EC 1.6.99.6] and of $\beta$-glucuronidase [EC 3.2.1.31] release from azurophilic granules [3].

Although $\mathrm{fMLP}, \mathrm{C} 5 \mathrm{a}$ and $\mathrm{LTB}_{4}$ all effectively activate $G_{i}$-proteins as assessed by measurement of high-

* Corresponding author. Tel. 4930838 2064; FAX 49 308315954 .

$\dagger$ Abbreviations: $\mathrm{Bt}_{2} \mathrm{cAMP}$, dibutyryl cAMP; $\left[\mathrm{Ca}^{2+}\right]_{\mathrm{i}}$, cytosolic $\mathrm{Ca}^{2+}$ concentration; CTX, cholera toxin; DMSO, dimethyl sulfoxide; fMLP, $N$-formyl-L-methionyl-L-leucylL-phenylalanine; G-proteins, guanine nucleotide-binding proteins; GTP $[\gamma \mathrm{S}]$, guanosine $5^{\prime}-O$-[3-thio]triphosphate; $\mathrm{LTB}_{4}$, leukotriene $\mathrm{B}_{4} ; \mathrm{O}_{2}^{-}$, superoxide anion; $\mathrm{PTX}$, pertussis toxin. affinity GTP hydrolysis and GTP $[\gamma \mathrm{S}]$ binding and photolabeling of $\alpha$-subunits with GTP azidoanilide [4-6], substantial differences in the effects of fMLP and $\mathrm{LTB}_{4}$ have been observed. Specifically, $\mathrm{LTB}_{4}$, unlike fMLP, does not enhance CTX-catalysed ADPribosylation of $\mathrm{G}_{\mathrm{i}}$-protein $\alpha$-subunits in membranes of DMSO-differentiated HL-60 cells [7, 8]. In addition, $\mathrm{LTB}_{4}$, in marked contrast to fMLP, is only a poor activator of NADPH oxidase in neutrophils and DMSO-differentiated HL-60 cells [7,9]. From these data it was concluded that fMLP and $\mathrm{LTB}_{4}$ induce different activation states of $\mathrm{G}_{\mathrm{i}}$-proteins, resulting in different cellular responses $[7,8]$. Some data indicate that there are also differences in the effects of fMLP and $\mathrm{C} 5 \mathrm{a}$ in neutrophils and HL-60 cells. For example, C5a-induced NADPH oxidase activation in neutrophils is more rapid in onset than that induced by fMLP, but the response towards C5a is transient $[10,11]$. In addition, C5a is substantially more potent than fMLP in activating rises in cytosolic $\mathrm{Ca}^{2+}$ concentration $\left(\left[\mathrm{Ca}^{2+}\right]_{\mathrm{i}}\right)$ in HL-60 cells and $\beta$-glucuronidase release in neutrophils $[12,13]$. Moreover, cAMP-increasing substances differentially inhibit fMLP- and C5ainduced $\beta$-glucuronidase release $[11,12]$. Finally, a cell-permeant analog of cGMP and NO-containing substances enhance the stimulatory effects of C5a on $\mathrm{O}_{2}^{-}$formation and/or exocytosis, whereas the effects of fMLP are inhibited by these substances $[11,12]$.

In order to learn more about the signal transduction 


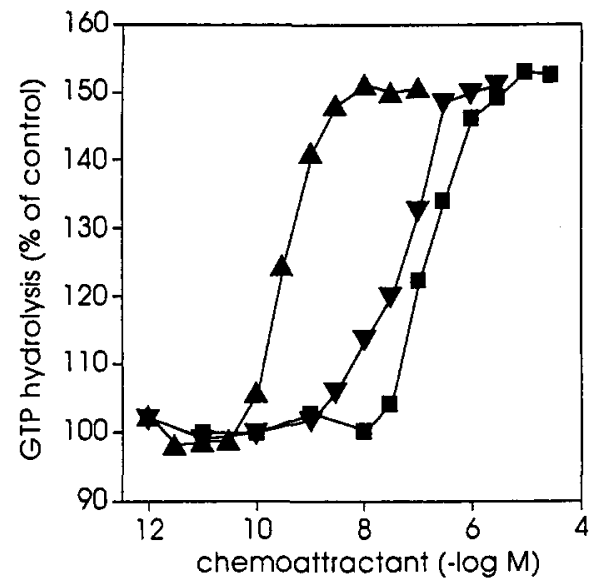

Fig. 1. Concentration-response curves for chemoattractants on high-affinity GTP hydrolysis in HL-60 membranes. High-affinity GTPase activity in HL-60 membranes was determined as described in Materials and Methods in the presence of fMLP ( $\boldsymbol{\square})$, C5a $(\boldsymbol{\Delta})$ and $\mathrm{LTB}_{4}(\boldsymbol{\nabla})$ at the indicated concentrations. Data shown are the means of assay quadruplicates. The SD values were generally less than $5 \%$ of the means. Basal GTP hydrolysis amounted to $24.4 \pm 0.5 \mathrm{pmol} / \mathrm{mg} / \mathrm{min}$. Similar results as those shown were obtained in three independent experiments.

pathways activated by $\mathrm{C} 5 \mathrm{a}$, we studied the effects of C5a in comparison to those of fMLP and $\mathrm{LTB}_{4}$ in intact $\mathrm{Bt}_{2} \mathrm{CAMP}$-differentiated HL-60 cells and in membranes of these cells. Here, we show that there are not only differences in the state of $\mathrm{G}_{\mathrm{i}}$-protein activation induced by $\mathrm{fMLP}$ and $\mathrm{LTB}_{4}$, but also between FMLP and C5a as well as between C5a and $\mathrm{LTB}_{4}$.

\section{MATERIALS AND METHODS}

Materials. Human recombinant C5a, fMLP and $\mathrm{LTB}_{4}$ were obtained from Sigma Chemie (Deisenhofen, Germany). PTX was obtained from List Biological Laboratories (Campbell, CA, U.S.A.). $\left.{ }^{35} \mathrm{~S}\right] \mathrm{GTP}[\gamma \mathrm{S}](1000-1500 \mathrm{Ci} / \mathrm{mmol})$ was obtained from Dupont/New England Nuclear (Bad Homburg, Germany). Sources of other materials have been described elsewhere [12-20].

Cell culture and membrane preparation. HL-60 cells were grown in suspension culture at $37^{\circ}$ and were differentiated towards neutrophil-like cells with $\mathrm{Bt}_{2}$ cAMP $(0.2 \mathrm{mM})$ for $48 \mathrm{hr}$ [15]. HL-60 membranes were prepared as described [14, 16]. PTX (100 ng/ $\mathrm{mL}$ ) or its carrier (control) were added to cell cultures $24 \mathrm{hr}$ before experiments with intact cells or membrane preparation. Under these conditions, virtually all $\mathrm{G}_{\mathrm{i}}$-protein $\alpha$-subunits were ADPribosylated as assessed by in vitro ADP-ribosylation of membranes with activated PTX and [ ${ }^{32}$ P]NAD (data not shown).

GTPase assay. High-affinity GTP hydrolysis was determined as described [16]. In brief, reaction mixtures $(100 \mu \mathrm{L})$ contained HL-60 membranes (3.0-7.0 $\mu \mathrm{g}$ of protein/tube), $0.5 \mu \mathrm{M}\left[\gamma_{-}{ }^{32} \mathrm{P}\right] \mathrm{GTP}$
$(0.1 \mu \mathrm{Ci} /$ tube $), 0.5 \mathrm{mM} \mathrm{MgCl}_{2}, 0.1 \mathrm{mM}$ EGTA, $0.1 \mathrm{mM}$ ATP, $1 \mathrm{mM}$ adenosine $5^{\prime}$-[ $\beta, \gamma$-imido]triphosphate, $5 \mathrm{mM}$ creatine phosphate, $40 \mu \mathrm{g}$ of creatine kinase, $1 \mathrm{mM}$ dithiothreitol, $0.2 \%(\mathrm{w} / \mathrm{v})$ bovine serum albumin in $50 \mathrm{mM}$ triethanolamine/ $\mathrm{HCl}, \mathrm{pH} 7.4$, and chemoattractants at various concentrations. Reactions were conducted for $15 \mathrm{~min}$ at $25^{\circ}$.

$G T P[\gamma S]$ binding assay. GTP $[\gamma \mathrm{S}]$ binding as described recently [17] was carried out with few modifications. Briefly, reaction mixtures $(100 \mu \mathrm{L})$ contained HL-60 membranes (3.0-5.0 $\mu \mathrm{g}$ of protein/ tube), $0.4 \mathrm{nM}\left[{ }^{35} \mathrm{~S}\right] \mathrm{GTP}[\gamma \mathrm{S}](50 \mathrm{nCi} /$ tube $), 5 \mathrm{mM}$ $\mathrm{MgCl}_{2}, 1 \mathrm{mM}$ EDTA, $1 \mathrm{mM}$ dithiothreitol, $3 \mu \mathrm{M}$ GDP, $0.2 \%(\mathrm{w} / \mathrm{v})$ bovine serum albumin in $50 \mathrm{mM}$ triethanolamine $/ \mathrm{HCl}, \mathrm{pH} 7.4$, and various chemoattractants. Reactions were conducted for $30 \mathrm{~min}$ at $25^{\circ}$.

Assay for photolabeling of membrane proteins and immunoprecipitation of photolabeled proteins. HL60 membranes ( $200 \mu \mathrm{g}$ of protein in a total volume of $120 \mu \mathrm{L}$ ) were incubated at $30^{\circ}$ in a buffer consisting of $0.1 \mathrm{mM}$ EDTA, $5 \mathrm{mM} \mathrm{MgCl}_{2}, 1 \mathrm{mM}$ benzamidine, $10 \mu \mathrm{M}$ GDP, $10 \mathrm{mM} \mathrm{NaCl}$ and $30 \mathrm{mM}$ HEPES/ $\mathrm{NaOH}, \mathrm{pH}$ 7.4. After exposure to various chemoattractants for $3 \mathrm{~min}$, samples were incubated for another 3 min with $10 \mathrm{nM}\left[\alpha^{32}\right.$ P]GTP azidoanilide ( $3.5 \mu \mathrm{Ci} /$ tube). The stopping of reactions, washing and irradiation of samples were performed as described [19]. Immunoprecipitation of photolabeled G-protein $\alpha$-subunits was performed with the antipeptide antiserum, $a_{i}$ common (AS 266), as described [20].

Assay for CTX-catalysed ADP-ribosylation of membrane proteins. ADP-ribosylation was determined according to Klinker et al. [16]. In brief, reaction mixtures $(50 \mu \mathrm{L})$ contained HL-60 membranes ( $50 \mu \mathrm{g}$ of protein/tube), $3 \mu \mathrm{M}\left[{ }^{32} \mathrm{P}\right]$ NAD $(5 \mu \mathrm{Ci} /$ tube $), 3 \mathrm{mM} \mathrm{MgCl}, 1 \mathrm{mM}$ ATP, $10 \mathrm{mM}$ thymidine, $0.2 \%(\mathrm{w} / \mathrm{v})$ bovine serum albumin, $2 \mu \mathrm{g}$ of activated CTX and $0.1 \mathrm{M}$ potassium phosphate, $\mathrm{pH} 7.4$, in the presence of various chemoattractants. Reactions were conducted for $60 \mathrm{~min}$ at $30^{\circ}$.

Miscellaneous Protein was determined according to Lowry et al. [21]. [ $\left.\gamma^{32} \mathrm{P}\right] \mathrm{GTP}$ was prepared as described [22]. [ $\left.\alpha^{-32} \mathrm{P}\right] \mathrm{GTP}$ azidoanilide was prepared according to Offermanns et al. [19]. [ $\left.{ }^{32} \mathrm{P}\right]-$ NAD was synthesized according to Cassel and Pfeuffer [23]. SDS-PAGE, immunoblotting and autoradiography were performed as described by Rosenthal et al. [18]. Immunoblotting studies using anti-peptide antisera, $\alpha_{\mathrm{i}}$ common (AS 266), $\alpha_{\mathrm{i} 2}$ (AS 269) and $\alpha_{\mathrm{i} 3}$ (AS 105) [20], revealed that photolabeled and ADP-ribosylated 40 and $41 \mathrm{kDa}$ proteins in membranes of $\mathrm{Bt}_{2} \mathrm{cAMP}$-differentiated HL-60 cells corresponded to $G_{i \alpha 2}$ and $G_{i \alpha 3}$, respectively (data not shown). $\left[\mathrm{Ca}^{2+}\right]_{\mathrm{i}}$ was determined using the fluorescent dye, Fura-2, as described [13]. $\mathrm{O}_{2}{ }^{-}$ formation was monitored at $550 \mathrm{~nm}$ by continuous measurement of ferricytochrome $\mathrm{C}$ reduction inhibitable by superoxide dismutase [EC 1.15.1.1], using an Uvikon 810 dual beam spectrophotometer (Kontron, Eching, Germany) [15]. The absolute amounts of $\mathrm{O}_{2}^{-}$generated within $10 \mathrm{~min}$ were calculated. $\beta$-Glucuronidase release was determined as described by Wenzel-Seifert and Seifert [24]. 
Table 1. Chemoattractant-stimulated high-affinity GTP hydrolysis and GTP $[\gamma \mathrm{S}]$ binding in HL-60 membranes: effect of PTX

\begin{tabular}{lccccc}
\hline & \multicolumn{2}{c}{$\begin{array}{c}\text { GTP hydrolysis } \\
(\mathrm{pmol} / \mathrm{mg} / \mathrm{min})\end{array}$} & & \multicolumn{2}{c}{$\begin{array}{c}\text { GTP }[\gamma \mathrm{\gamma}] \text { binding } \\
(\mathrm{pmol} / \mathrm{mg})\end{array}$} \\
\cline { 2 - 3 } \cline { 5 - 6 } \multicolumn{1}{c}{ Stimulus } & Control & PTX & & Control & PTX \\
\hline $\mathrm{H}_{2} \mathrm{O}$ (solvent) & $26.0 \pm 0.9$ & $15.4 \pm 0.8$ & & $1.09 \pm 0.05$ & $0.62 \pm 0.01$ \\
fMLP & $47.7 \pm 2.1$ & $14.8 \pm 0.5$ & & $2.71 \pm 0.13$ & $0.63 \pm 0.02$ \\
C5a & $48.9 \pm 1.0$ & $14.2 \pm 0.4$ & & $2.65 \pm 0.07$ & $0.62 \pm 0.02$ \\
LTB $_{4}$ & $44.7 \pm 0.7$ & $15.5 \pm 1.1$ & & $2.81 \pm 0.10$ & $0.64 \pm 0.03$ \\
\hline
\end{tabular}

Treatments with carrier (control) and PTX were performed as described in Materials and Methods. High-affinity GTPase activity and GTP $[\gamma \mathrm{S}]$ binding in HL-60 membranes were determined as described in "Materials and Methods". The concentrations of AMLP, C5a and $\mathrm{LTB}_{4}$ were $10 \mu \mathrm{M}, 10 \mathrm{nM}$ and $1 \mu \mathrm{M}$, respectively. For determination of basal GTP hydrolysis, $\mathrm{H}_{2} \mathrm{O}$ (solvent) was added instead of stimulus. Data shown are the means $\pm \mathrm{SD}$ of assay quadruplicates. Similar results were obtained in four independent experiments.

Table 2. Effects of chloride salts of monovalent cations on chemoattractant-stimulated highaffinity GTP hydrolysis in HL-60 membranes

\begin{tabular}{lccccc}
\hline & \multicolumn{5}{c}{ GTP hydrolysis (\% stimulation) } \\
\cline { 2 - 6 } Stimulus & Solvent $\left(\mathrm{H}_{2} \mathrm{O}\right)$ & $\mathrm{NaCl}$ & $\mathrm{KCl}$ & $\mathrm{LiCl}$ & Choline chloride \\
\hline fMLP & 80 & 123 & 160 & 118 & 127 \\
C5a & 84 & 57 & 71 & 45 & 77 \\
$\mathrm{LTB}_{4}$ & 65 & 145 & 146 & 116 & 84
\end{tabular}

High-affinity GTPase activity in HL-60 membranes was determined in the presence of various chloride salts of monovalent cations $(150 \mathrm{mM}$ each) or solvent as described in Materials and Methods. The concentrations of fMLP, C5a and $\mathrm{LTB}_{4}$ were $10 \mu \mathrm{M}, 10 \mathrm{nM}$ and $1 \mu \mathrm{M}$, respectively. Data shown are the means of assay quadruplicates. The SD values were generally less than $5 \%$ of the means. Basal GTP hydrolyses in the presence of solvent, $\mathrm{NaCl}, \mathrm{KCl}, \mathrm{LiCl}$ and choline chloride were $20.2 \pm 0.6,20.3 \pm 0.5,19.6 \pm 0.3,25.3 \pm 0.4$ and $19.0 \pm 0.5 \mathrm{pmol} / \mathrm{mg} / \mathrm{min}$, respectively. The stimulatory effects of chemoattractants are referred to these basal GTP hydrolyses. Similar results as those shown were obtained in three independent experiments.

\section{RESULTS}

We first studied the effects of chemoattractants on high-affinity GTPase activity (EC 3.6.1.-) in HL60 membranes. fMLP activated GTP hydrolysis with an $\mathrm{EC}_{50}$ of $190 \mathrm{nM}$ and a plateau at $10-30 \mu \mathrm{M}$ (Fig. 1). The corresponding values for $\mathrm{C} 5 \mathrm{a}$ were $300 \mathrm{pM}$ and $10-100 \mathrm{nM}$, respectively. The $\mathrm{EC}_{50}$ of $\mathrm{LTB}_{4}$ for GTPase stimulation was $60 \mathrm{nM}$, and a plateau was reached at $1-3 \mu \mathrm{M}$. At maximally stimulatory concentrations, the chemoattractants were similarly effective in activating GTP hydrolysis. As has been shown for fMLP in HL-60 membranes [16], C5a and $\mathrm{LTB}_{4}$ also increased $V_{\max }$ of GTP hydrolysis (data not shown).

Table 1 compares the effects of chemoattractants at maximally stimulatory concentrations on GTP hydrolysis and GTP $[\gamma \mathrm{S}]$ binding in control membranes and in membranes of PTX-treated HL-60 cells. As was the case for GTP hydrolysis, fMLP, $\mathrm{C5a}$ and $\mathrm{LTB}_{4}$ were similarly effective in stimulating GTP $[\gamma S]$ binding. PTX abolished the stimulatory effects of chemoattractants on GTPase and GTP $[\gamma S]$ binding.

Chloride salts of monovalent cations enhance
fMLP-induced GTPase activation in HL-60 membranes, presumably through an alteration of receptor/ G-protein interaction $[3,25] . \mathrm{NaCl}, \mathrm{KCl}, \mathrm{LiCl}$ and choline chloride ( $150 \mathrm{mM}$ each) enhanced the relative stimulatory effects of fMLP on GTPase in HL-60 membranes by $54,100,48$ and $59 \%$, respectively (Table 2). The corresponding values for $\mathrm{LTB}_{4}$ were $123,125,78$ and $29 \%$, respectively. In contrast, $\mathrm{NaCl}, \mathrm{KCl}, \mathrm{LiCl}$ and choline chloride diminished C5a-stimulated GTP hydrolysis by 32, 15, 46 and $8 \%$, respectively.

Next, we assessed the effects of AMLP, C5a and $\mathrm{LTB}_{4}$ on photolabeling of $\mathrm{G}_{\mathrm{i}}$-protein $\alpha$-subunits with GTP azidoanilide. After photolabeling, G-protein $\alpha$-subunits were immunoprecipitated with the $\alpha_{i}$ common antiserum and then subjected to SDSPAGE and autoradiography. fMLP, C5a and LTB $_{4}$ were similarly effective in enhancing incorporation of GTP azidoanilide into $40 \mathrm{kDa}$ proteins $\left(\mathrm{G}_{\mathrm{i} \alpha 2}\right)$ and into $41 \mathrm{kDa}$ proteins $\left(\mathrm{G}_{\mathrm{i} \alpha 3}\right)$ (Fig. 2). The abundance of $G_{i \alpha 2}$ in HL-60 cells is much higher than that of $\mathrm{G}_{\mathrm{i} \alpha 3}[6,26]$, so that the intensity of labeling of the latter protein is considerably lower than that of the former. 


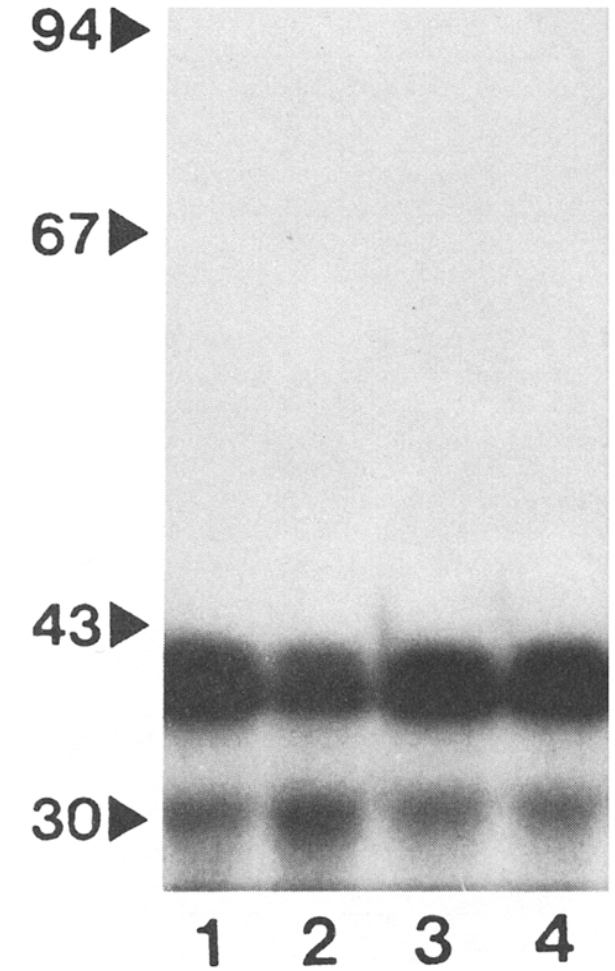

Fig. 2. Effects of chemoattractants on incorporation of GTP azidoanilide into $\mathrm{G}_{\mathrm{i}}$-protein $\alpha$-subunits in HL-60 membranes. Photolabeling and immunoprecipitation were performed as described in Materials and Methods. The autoradiogram of an SDS gel containing $4.3 \mathrm{M}$ urea and $8 \%(\mathrm{w} / \mathrm{v})$ acrylamide is shown. Lane 1 , fMLP $(10 \mu \mathrm{M})$; lane $2, \mathrm{H}_{2} \mathrm{O}$ added instead of stimulus (control); lane 3, $\mathrm{LTB}_{4}(1 \mu \mathrm{M})$; lane 4 , C5a $(1 \mu \mathrm{M})$. Numbers on the left, molecular masses of marker proteins (kDa). $40 \mathrm{kDa}$ proteins represent $G_{i \alpha 2}$, and $41 \mathrm{kDa}$ proteins represent $\mathrm{G}_{\mathrm{i} \alpha 3}$. The autoradiogram shown is representative of four independent experiments.

Labeling of a $31 \mathrm{kD}$ a protein with GTP azidoanilide was observed as well (see Fig. 2). Unlike 40 and $41 \mathrm{kDa}$ proteins, chemoattractants did not enhance labeling of the $31 \mathrm{kDa}$ protein. Thus, the $31 \mathrm{kDa}$ protein may represent a proteolytic fragment of $\mathrm{G}_{\mathrm{i} \alpha 2}$ and/or $G_{i a 3}$ which still binds GTP azidoanilide but no longer interacts with chemoattractant receptors.

The effects of chemoattractants on CTX-catalysed ADP-ribosylation of $\mathrm{G}_{i}$-protein $\alpha$-subunits were studied as well. As has been shown for membranes of DMSO-differentiated HL-60 cells [7], $\mathrm{LTB}_{4}$ $(1 \mu \mathrm{M})$ did not enhance ADP-ribosylation of $\mathrm{G}_{\mathrm{i}}-$ protein $\alpha$-subunits in membranes of $\mathrm{Bt}_{2} \mathrm{cAMP}$ differentiated HL-60 cells either (data not shown). In contrast, fMLP $(1 \mu \mathrm{M})$ effectively stimulated CTX-catalysed ADP-ribosylation of $\mathrm{G}_{\mathrm{i} \alpha 2}$ and $\mathrm{G}_{\mathrm{i} \alpha 3}$ (Fig. 3). By comparison to fMLP, C5a (10 nM$1 \mu \mathrm{M})$ was considerably less effective in enhancing ADP-ribosylation of $G_{\mathrm{i} \alpha 2}$ and, specifically, of $G_{\mathrm{i} \alpha 3}$.

Time courses of the rises in $\left[\mathrm{Ca}^{2+}\right]_{i}$ caused by chemoattractants at maximally stimulatory concentrations [13] are shown in Fig. 4. fMLP, C5a

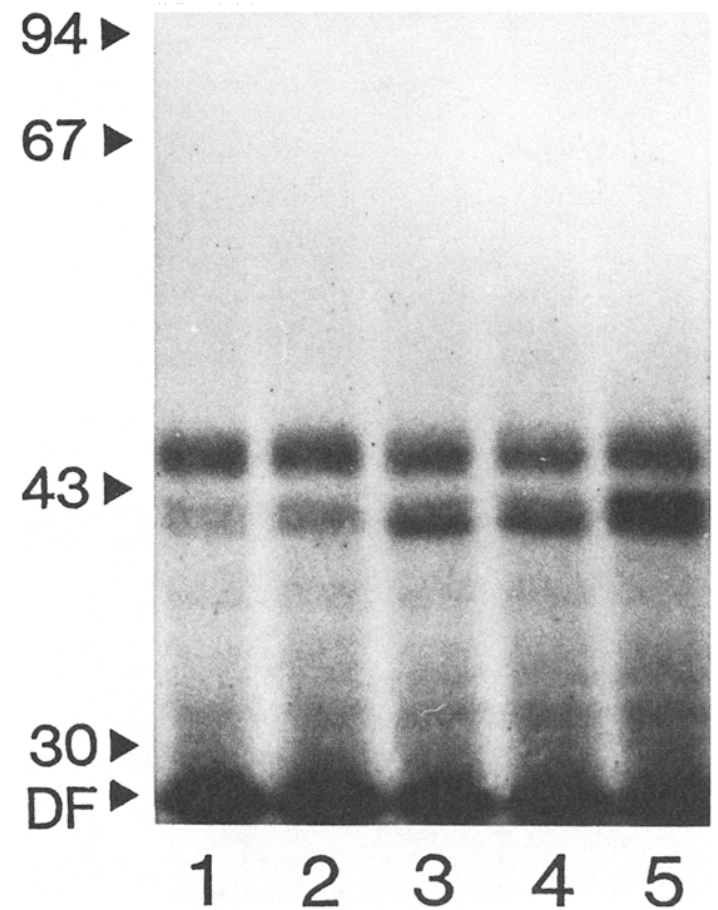

Fig. 3. Effects of fMLP and C5a on CTX-catalysed ADPribosylation of $\mathrm{G}_{i}$-protein $\alpha$-subunits in HL-60 membranes. CTX-catalysed ADP-ribosylation was performed as described in Materials and Methods. The autoradiogram of an SDS gel containing $4.3 \mathrm{M}$ urea and $9 \%(\mathrm{w} / \mathrm{v})$ acrylamide is shown. Lane $1, \mathrm{H}_{2} \mathrm{O}$ added instead of stimulus (control); lane 2, C5a (10 nM); lane 3, C5a (100 nM); lane 4 , C5a $(1 \mu \mathrm{M})$; lane 5, fMLP $(1 \mu \mathrm{M})$. Numbers on the left, molecular masses of marker proteins $(\mathrm{kDa})$. DF, dye front. $40 \mathrm{kDa}$ proteins represent $\mathrm{G}_{\mathrm{i \alpha} 2}$, and $41 \mathrm{kDa}$ proteins represent $G_{i \alpha 3}$. The autoradiogram shown is representative of three independent experiments.

and $\mathrm{LTB}_{4}$ induced rapid rises in $\left[\mathrm{Ca}^{2+}\right]_{\mathrm{i}}$. The peak $\left[\mathrm{Ca}^{2+}\right]_{\mathrm{i}}$ values stimulated by $\mathrm{fMLP}$ and $\mathrm{C} 5 \mathrm{a}$ were higher than those induced by $\mathrm{LTB}_{4}$. In the absence of extracellular $\mathrm{Ca}^{2+}$, chemoattractant-induced rises in $\left[\mathrm{Ca}^{2+}\right]_{\mathrm{i}}$ were shorter than in its presence. These data indicate that fMLP, C5a and $\mathrm{LTB}_{4}$ induced both $\mathrm{Ca}^{2+}$ mobilization from intracellular stores and $\mathrm{Ca}^{2+}$ influx from the extracellular space. The imidazole, $\quad 1-\{\beta-[3-(4-$ methoxyphenyl)propoxyl]-4methoxyphenethyl-1 $H$-imidazole hydrochloride (SK\&F 96365), reduces fMLP-induced $\mathrm{Ca}^{2+}$ influx through non-selective cation channels in $\mathrm{Bt}_{2} \mathrm{cAMP}-$ differentiated HL-60 cells [3]. SK\&F $96365(30 \mu \mathrm{M})$ inhibited $\mathrm{C} 5 \mathrm{a}-$ and $\mathrm{LTB}_{4}$-induced $\mathrm{Ca}^{2+}$ influxes to the same extent as that induced by PMLP (data not shown), indicating that they were mediated through non-selective cation channels as well. C5a- and $\mathrm{LTB}_{4}$-induced $\mathrm{Ca}^{2+}$ influxes declined more rapidly than fMLP-induced $\mathrm{Ca}^{2+}$ influx. Chemoattractantinduced $\mathrm{Ca}^{2+}$ mobilizations were blocked by PTX. With respect to $\mathrm{Ca}^{2+}$ influx, approx $20 \%$ of the effect of fMLP was PTX-insensitive. In comparison, PTX inhibited C5a- and $\mathrm{LTB}_{4}$-induced $\mathrm{Ca}^{2+}$ influxes almost completely. 


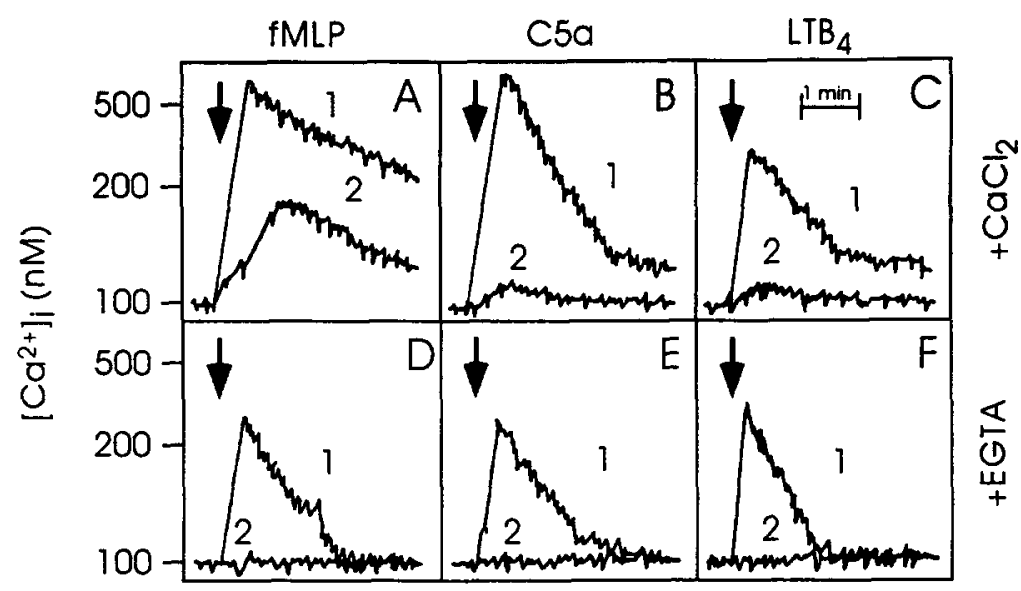

Fig. 4. Chemoattractant-induced rises in $\left[\mathrm{Ca}^{2+}\right]_{\mathrm{i}}$ in HL-60 cells: effect of PTX. Determinations of $\left[\mathrm{Ca}^{2+}\right]_{\mathrm{i}}$ were performed as described in Materials and Methods. The increases in $\left[\mathrm{Ca}^{2+}\right]_{\mathrm{i}}$ induced by fMLP $(1 \mu \mathrm{M}), \mathrm{C} 5 \mathrm{a}(10 \mathrm{nM})$ and $\mathrm{LTB}_{4}(10 \mathrm{nM})$ in the presence of $1 \mathrm{mM}$ extracellular $\mathrm{CaCl}_{2}(\mathrm{~A}-\mathrm{C})$ or $1 \mathrm{mM}$ extracellular EGTA (D-F) were assessed. Treatments with carrier (control) (traces 1) and PTX (traces 2) were performed as described in Materials and Methods. Arrows indicate the addition of chemoattractants. Superimposed original fluorescence tracings are shown. Similar results were obtained in four experiments with different preparations of HL-60 cells.

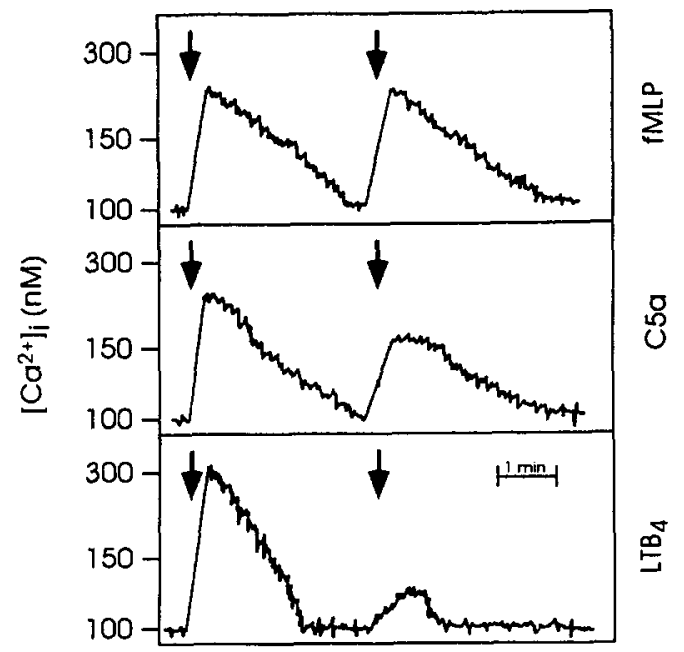

Fig. 5. Homologous desensitization of chemoattractantinduced rises in $\left[\mathrm{Ca}^{2+}\right]_{i}$ in HL-60 cells. Determinations of $\left[\mathrm{Ca}^{2+}\right]_{i}$ were performed as described in Materials and Methods. The increases in $\left[\mathrm{Ca}^{2+}\right]_{\mathrm{i}}$ induced by chemoattractants in the presence of $1 \mathrm{mM}$ extracellular $\mathrm{CaCl}_{2}$ were assessed. The arrows on the left indicate the additions of fMLP $(2 \mathrm{nM}), \mathrm{C} 5 \mathrm{a}(0.3 \mathrm{nM})$ and $\mathrm{LTB}_{4}(3 \mathrm{nM})$, respectively. The arrows on the right indicate the repeated additions of chemoattractants at the same concentrations. Superimposed original fluorescence tracings are shown. Similar results were obtained in three experiments with different preparations of HL-60 cells.

Homologous desensitization of chemoattractantinduced rises in $\left[\mathrm{Ca}^{2+}\right]_{\mathrm{i}}$ was determined. $\mathrm{HL}-60$ cells were stimulated with fMLP, C5a and $\mathrm{LTB}_{4}$ at submaximally effective concentrations and were re-
Table 3. Effects of chemoattractants on $\mathrm{O}_{2}^{-}$formation and $\beta$-glucuronidase release in $\mathrm{HL}-60$ cells

\begin{tabular}{lcc}
\hline Stimulus & $\begin{array}{c}\mathrm{O}_{2}^{-} \text {formation } \\
\left(\mathrm{nmol} / 10^{6} \text { cells }\right)\end{array}$ & $\begin{array}{c}\beta \text {-glucuronidase release } \\
(\% \text { of cellular content })\end{array}$ \\
\hline fMLP & $2.5 \pm 0.3$ & $34.1 \pm 3.3$ \\
C5a & $1.3 \pm 0.2$ & $21.3 \pm 2.0$ \\
LTB $_{4}$ & 0 & 0
\end{tabular}

$\mathrm{O}_{2}^{-}$formation and $\beta$-glucuronidase release in HL-60 cells were determined as described in Materials and Methods. The concentrations of fMLP, C5a and $\mathrm{LTB}_{4}$ were $1 \mu \mathrm{M}, 100 \mathrm{nM}$ and $1 \mu \mathrm{M}$, respectively. In the absence of stimuli, $\mathrm{HL}-60$ cells did not generate $\mathrm{O}_{2}^{-}$. Basal $\beta$ glucuronidase release in the absence of stimuli was $5.5 \pm 0.6 \%$ of the cellular content. Data shown are the means \pm SD of assay quadruplicates. Similar results were obtained in three independent experiments.

challenged with the chemoattractants at the same concentrations after $3 \mathrm{~min}$, i.e. after $\left[\mathrm{Ca}^{2+}\right]_{\mathrm{i}}$ had again reached basal values (Fig. 5). Under these conditions, the second response to FMLP was not diminished, whereas those to C5a and $\mathrm{LTB}_{4}$ were reduced by 50 and $85 \%$, respectively.

Finally, we compared the effects of chemoattractants on $\mathrm{O}_{2}^{-}$formation and $\beta$-glucuronidase release in $\mathrm{HL}-60$ cells. At maximally stimulatory concentrations, C5a was approx. 50\% less effective than fMLP in activating $\mathrm{O}_{2}^{-}$formation (Table 3). $\mathrm{LTB}_{4}$ did not activate $\mathrm{O}_{2}{ }^{-}$formation. PTX abolished the stimulatory effects of fMLP and $\mathrm{C} 5 \mathrm{a}$ on $\mathrm{O}_{2}{ }^{-}$ formation (data not shown). With respect to exocytosis, C5a was approx. $40 \%$ less effective than fMLP in stimulating the release of $\beta$-glucuronidase (see Table 3). 


\section{DISCUSSION}

The aim of our study was to characterize C5amediated signal transduction pathways in $\mathrm{Bt}_{2} \mathrm{cAMP}$ differentiated HL-60 cells. Specifically, we were interested in determining whether there are differences between fMLP and C5a and between $\mathrm{C} 5 \mathrm{a}$ and $\mathrm{LTB}_{4}$. The three chemoattractants were similarly effective in activating GTP hydrolysis, GTP $[\gamma \mathrm{S}]$ binding and $\mathrm{Ca}^{2+}$ mobilization, the latter parameter reflecting phospholipase $\mathrm{C}$ activation, and their effects were completely PTX-sensitive (see Table 1 and Fig. 4). Thus, fMLP, C5a and $\mathrm{LTB}_{4}$ activate $\mathrm{G}_{\mathrm{i}}$-proteins in $\mathrm{Bt}_{2} \mathrm{cAMP}$-differentiated $\mathrm{HL}$ 60 cells. Similar data have been obtained for human neutrophils and DMSO-differentiated HL-60 cells $[4,5,7]$.

In order to ascertain which $\mathrm{G}_{\mathrm{i}}$-protein subtypes are activated by chemoattractants, we photolabeled $\mathrm{G}_{\mathrm{i}}$-protein $\alpha$-subunits with GTP azidoanilide. In agreement with the data obtained for membranes of DMSO-differentiated HL-60 cells, we found that chemoattractants were similarly effective in activating $\mathrm{G}_{\mathrm{i} \alpha 2}$ in membranes of $\mathrm{Bt}_{2} \mathrm{cAMP}$-differentiated HL60 membranes (see Fig. 2) [6]. In our previous study [6], we were unable to determine whether fMLP, C5a and $\mathrm{LTB}_{4}$ also activate $\mathrm{G}_{\mathrm{i} \alpha 3}$ in HL-60 membranes. This could have been due to the lack of resolution of $\mathrm{G}_{\mathrm{i} \alpha 2}$ and $\mathrm{G}_{\mathrm{i} \alpha 3}$ on SDS-PAGE [6]. Another reason could have been that the concentration ratio $G_{i a 2} /$ $\mathrm{G}_{\mathrm{i} \alpha 3}$ in HL-60 membranes is high $[6,25]$, so that the strong labeling of a $G_{i \alpha 2}$ masked that of $G_{i \alpha 3}$. Therefore, we increased the sensitivity of the method by immunoprecipitating $\mathrm{G}_{\mathrm{i}}$-protein $\alpha$-subunits with the anti-peptide antiserum, $\alpha_{\mathrm{i}}$ common, before performing SDS-PAGE and by including urea into the gel. Under these conditions, labeling of $\mathrm{G}_{\mathrm{i} 33}$ was, in fact, evident. As was the case for $G_{i \alpha 2}$, chemoattractants were similarly effective in increasing photolabeling of $\mathrm{G}_{\mathrm{i} \alpha 3}$ (see Fig. 2).

However, when CTX-catalysed ADP-ribosylation is considered, substantial differences between AMLP, C5a and $\mathrm{LTB}_{4}$ become apparent. Specifically, C5a activated ADP-ribosylation of $G_{i \alpha 2}$ and, particularly, of $G_{i \alpha 3}$ much less effectively than fMLP, and LTB $_{4}$ was ineffective (see Fig. 3). Intriguingly, there was no difference in the extent of ADP-ribosylation of $\mathrm{G}_{\mathrm{i} \alpha 2}$ and $\mathrm{G}_{\mathrm{i} \alpha 3}$ in the presence of fMLP, whereas with respect to incorporation of GTP azidoanilide, labeling of $G_{i \alpha 2}$ was much more prominent than that of $\mathrm{G}_{\mathrm{i} a 3}$ (compare lane 1 in Fig. 2 with lane 5 in Fig. 3). These differences between CTX-catalysed ADPribosylation and photolabeling and the data concerning GTP hydrolysis and GTP $[\gamma \mathrm{S}]$ binding (see Table 1) indicate that the former parameter is not suitable to assess quantitatively $G_{i}$-protein activation by chemoattractants. Rather, CTXcatalysed ADP-ribosylation is useful in revealing qualitative differences in the $G_{i}$-protein activation state caused by fMLP, C5a and $\mathrm{LTB}_{4}$.

Differences in the effects of chemoattractants on $\mathrm{G}_{\mathrm{i}}$-protein activation were not only apparent with respect to CTX-catalysed ADP-ribosylation but also with regard to the effects of chloride salts of monovalent cations on GTP hydrolysis. Specifically, cations enhanced the effectiveness of fMLP and
$\mathrm{LTB}_{4}$ in activating GTP hydrolysis, whereas they decreased that of C5a (see Table 2). It is noteworthy that $\mathrm{NaCl}$ and $\mathrm{KCl}$ were similarly effective with respect to $\mathrm{LTB}_{4}$, but with respect to fMLP, $\mathrm{KCl}$ was more effective than $\mathrm{NaCl}$ (see Table 2). When C5a is considered, $\mathrm{LiCl}$ was the most effective inhibitor (see Table 2). Thus, the differential effects of salts on chemoattractant GTP hydrolyses support our assumption that there are not only qualitative differences in the $\mathrm{G}_{\mathrm{i}}$-protein activation state induced by fMLP and $\mathrm{LTB}_{4}$, but also between fMLP and C5a and between C5a and $\mathrm{LTB}_{4}$.

On the level of intact cells, we observed differences between the three chemoattractants as well. Specifically, the order of effectiveness of agonists in inducing $\mathrm{Ca}^{2+}$ influx was fMLP $>\mathrm{C} 5 \mathrm{a}>\mathrm{LTB}_{4}$ (see Fig. 4). In a recent study, we showed that $\mathrm{Ca}^{2+}$ influx is required for activation of $\mathrm{O}_{2}^{-}$formation and $\beta$-glucuronidase release [3]. In accordance with the aforementioned data, the order of effectiveness of chemoattractants in activating $\mathrm{O}_{2}{ }^{-}$formation and exocytosis was found to be fMLP $>\mathrm{C} 5 \mathrm{a}>\mathrm{LTB}_{4}$ (ineffective) (see Table 3). In agreement with our results, Stutchfield and Cockcroft [27] reported that C5a is less effective than fMLP in activating phosphatidic acid formation in $\mathrm{Bt}_{2} \mathrm{cAMP}$-differentiated HL-60 cells. Thus, fMLP is a full secretagogue, C5a is a partial secretagogue and $\mathrm{LTB}_{4}$ is an incomplete secretagogue (as it induces rises in $\left[\mathrm{Ca}^{2+}\right]_{\mathrm{i}}$ but not $\mathrm{O}_{2}^{-}$formation or exocytosis). Histamine, acting via $\mathrm{H}_{1}$-receptors, is also an incomplete secretagogue in $\mathrm{Bt}_{2} \mathrm{cAMP}$-differentiated HL-60 cells [28]. However, unlike the effects of $\mathrm{LTB}_{4}$ on $\left[\mathrm{Ca}^{2+}\right]_{i}$, those of histamine show substantial PTX-insensitivity (see Fig. 4) [28].

Differences in receptor desensitization may account, at least in part, for the differential effectiveness of chemoattractants in activating $\mathrm{Ca}^{2+}$ influx, $\mathrm{O}_{2}^{-}$formation and $\beta$-glucuronidase release. Indeed, the order of sensitivity of chemoattractants towards homologous desensitization was $\mathrm{LTB}_{4}>\mathrm{C} 5 \mathrm{a}>\mathrm{fMLP}$ (resistant) (see Fig. 5). This order correlates inversely with that concerning activation of $\mathrm{Ca}^{2+}$ influx, $\mathrm{O}_{2}^{-}$formation and exocytosis (compare Fig. 5 with Fig. 4 and Table 3 ). Like $\mathrm{LTB}_{4}$-induced rises in $\left[\mathrm{Ca}^{2+}\right]_{i}$, those induced by histamine in $\mathrm{Bt}_{2} \mathrm{cAMP}$-differentiated HL- 60 cells are very sensitive to homologous desensitization [28]. Differences in homologous desensitization of receptors could also provide an explanation for the findings that $\mathrm{C} 5 \mathrm{a}$-induced rises in $\left[\mathrm{Ca}^{2+}\right]_{\mathrm{i}}$ and NADPH oxidase activation are shorter than those induced by fMLP (see Fig. 4) [10, 11]. Interestingly, C5a receptors are also more sensitive to desensitization via protein kinase $\mathrm{C}$ than formyl peptide receptors [29]. In contrast, cAMP-increasing substances inhibit fMLP-induced exocytosis, whereas C5a-induced $\beta$-glucuronidase release is unaffected [12].

Quantitative differences in activation of $\mathrm{G}_{\mathrm{i}}$-protein $\alpha$-subunits do not contribute to the differential effects of fMLP, C5a and $\mathrm{LTB}_{4}$ on $\mathrm{Ca}^{2+}$ influx, $\mathrm{O}_{2}^{-}$ formation and exocytosis as they showed very similar effects on GTP hydrolysis, GTP $[\gamma S]$ binding and photolabeling (see Table 1 and Fig. 2). However, the differences between the chemoattractants 
concerning CTX-catalysed ADP-ribosylation (see Fig. 3) and regulation by chloride salts of monovalent cations (see Table 2) of GTP hydrolysis suggest that qualitative differences in $\mathrm{G}_{\mathrm{i}}$-protein activation states finally result in differential cellular effects of fMLP, C5a and LTB $_{4}$. The molecular basis for this differential $\mathrm{G}_{\mathrm{i}}$-protein activation remains to be determined.

Recently, Amatruda et al. [30] reported that in transfected COS-7 cells, C5a receptors mediate activation of phospholipase $\mathrm{C}$ through the PTXinsensitive G-protein, $G_{\alpha 16}$, a member of the $G_{g}$ family. Moreover, C5a activates phospholipase $C$ through a partially PTX-insensitive mechanism in the monocytic cell line, THP-1, which expresses $G_{\alpha 16}$ at high concentrations [30]. Furthermore, C5a mediates $\mathrm{Ca}^{2+}$ influx in $\mathrm{Bt}_{2}$ cAMP-differentiated U937 cells through a PTX-insensitive mechanism [31]. Evidently, activation by C5a of phospholipase $C$ via $G_{\alpha 16}$ or another PTX-insensitive $G$-protein of the $\mathrm{G}_{\mathrm{q}}$-family is not of relevance in $\mathrm{Bt}_{2} \mathrm{cAMP}$ differentiated $\mathrm{HL}-60$ cells, as C5a-induced $\mathrm{Ca}^{2+}$ mobilization was abolished by PTX (see Fig. 4). Additionally, PTX-insensitive G-proteins are also not of particular importance for mediation of C5ainduced $\mathrm{Ca}^{2+}$ influx in $\mathrm{Bt}_{2}$ cAMP-differentiated $\mathrm{HL}$ 60 cells (see Fig. 4). In human neutrophils, C5ainduced $\mathrm{Ca}^{2+}$-influx is PTX-sensitive as well [31]. Taken together, these findings show that the coupling of C5a receptors to $\mathrm{G}_{\mathrm{i}}$-proteins and PTX-insensitive $\mathrm{G}$-proteins in myeloid cells shows substantial cell type specificity.

Compared to C5a, fMLP-induced $\mathrm{Ca}^{2+}$ influx in $\mathrm{Bt}_{2} \mathrm{cAMP}$-differentiated HL-60 cells shows substantial PTX-insensitivity (see Fig. 4). However, fMLP did not show any stimulatory effect on GTPase and GTP $[\gamma$ S ] binding in membranes of PTX-treated cells (see Table 1). An explanation for this apparent discrepancy could be the fact that the guanine nucleotide exchange rates of PTX-insensitive Gproteins of the $G_{q}$-family are low [32] so that their activation in membranes is masked by the rapidly exchanging $\mathrm{G}_{\mathrm{i}}$-proteins.

In conclusion, fMLP, C5a and $\mathrm{LTB}_{4}$ activate the G-proteins, $G_{i \alpha 2}$ and $G_{i \alpha 3}$, in $B_{2} c A M P$-differentiated HL-60 cells, but they do so in different manners. Our data suggest that $\mathrm{G}_{\mathrm{i}}$-proteins are not static signal amplifiers, but that $\mathrm{G}_{\mathrm{i}}$-proteins transduce and enhance signals differentially, depending on the type of chemoattractant receptor being activated. Unlike fMLP , C5a is only a partial secretagogue in $\mathrm{Bt}_{2} \mathrm{cAMP}$ differentiated HL-60 cells and this may be due to differences in homologous receptor desensitization and qualitative $\mathrm{G}_{\mathrm{i}}$-protein activation.

Acknowledgements-The authors are grateful to Drs G. Schultz and K-L Langwitz for helpful comments, Dr K. Spicher for supplying peptide antisera and to Mrs E. Glaß and Miss $\mathrm{E}$. Bombien for expert technical assistance. We also thank Mrs M. Bigalke for photographic artwork. This work was supported by grants from the Deutsche Forschungsgemeinshaft

\section{REFERENCES}

1. Rossi $\mathrm{F}$, The $\mathrm{O}_{2}^{-}$-forming NADPH oxidase of the phagocytes: nature, mechanisms of activation and function. Biochim Biophys Acta 853: 65-89, 1986.
2. Seifert $R$ and Schultz G, The superoxide-forming NADPH oxidase of phagocytes: an enzyme system regulated by multiple mechanisms. Rev Physiol Biochem Pharmacol 117: 1-338, 1991.

3. Krautwurst D, Seifert R, Hescheler J and Schultz G, Formyl peptides and ATP stimulate $\mathrm{Ca}^{2+}$ and $\mathrm{Na}^{+}$ inward currents through non-selective cation channels via G-proteins in dibutyryl cyclic AMP-differentiated HL-60 cells. Involvement of $\mathrm{Ca}^{2+}$ and $\mathrm{Na}^{+}$in the activation of $\beta$-glucuronidase release and superoxide production. Biochem J 288: 1025-1035, 1992.

4. Feltner DE, Smith RH and Marasco WA, Characterization of the plasma membrane bound GTPase from rabbit neutrophils. I. Evidence for an $\mathrm{N}_{\mathrm{i}}$-like protein coupled to the formyl peptide, $\mathrm{C} 5 \mathrm{a}$, and leukotriene $\mathrm{B}_{4}$ chemotaxis receptors. J Immunol 137: 1961-1970, 1986.

5. Gierschik P, Moghtader R, Straub C, Dietrich K and Jakobs KH, Signal amplification in HL-60 granulocytes. Evidence that the chemotactic peptide receptor catalytically activates guanine-nucleotide-binding regulatory proteins in native plasma membranes. Eur $J$ Biochem 197: 725-732, 1991.

6. Offermanns S, Schäfer R, Hoffmann B, Bombien E, Spicher K, Hinsch K-D, Schultz G and Rosenthal W, Agonist-sensitive binding of a photoreactive GTP analog to a G-protein $\alpha$-subunit in membranes of $\mathrm{HL}$ 60 cells. FEBS Lett 260: 14-18, 1990.

7. McLeish KR, Gierschik P, Schepers T, Sidiropoulos D and Jakobs $\mathrm{KH}$, Evidence that activation of a common G-protein by receptors for leukotriene $\mathbf{B}_{4}$ and $\mathrm{N}$ formylmethionyl-leucyl-phenylalanine in HL-60 cells occurs by different mechanisms. Biochem $J$ 260: 427434, 1989.

8. Schepers TM and McLeish KR, Differential choleratoxin- and pertussis-toxin-catalysed ADP-ribosylation of G-proteins coupled to formyl-peptide and leukotriene $B_{4}$ receptors. Biochem J 289: 469-473, 1993.

9. Seifert R, Hilgenstock G, Fassbender $M$ and Distler A, Regulation of the superoxide-forming NADPH oxidase of human neutrophils is not altered in essential hypertension. J Hypertension 9: 147-153, 1991.

10. Wymann MP, von Tscharner V, Deranleau DA and Baggiolini $M$, The onset of the respiratory burst in human neutrophils. Real-time studies of $\mathrm{H}_{2} \mathrm{O}_{2}$ formation reveal a rapid agonist-induced transduction process. J Biol Chem 262: 12048-12053, 1987.

11. Ervens J, Schultz $G$ and Seifert R, Differential inhibition and potentiation of chemoattractant-induced superoxide anion formation in human neutrophils by the cell-permeant analogue of cyclic GMP, $N^{2}-2^{\prime}$ $O$-dibutyryl guanosine $3^{\prime}: 5^{\prime}$-cyclic monophosphate. Naunyn-Schmiedeberg's Arch Pharmacol 343: 370-376, 1991.

12. Wenzel-Seifert K, Ervens $\mathbf{J}$ and Seifert R, Differential inhibition and potentiation by cell-permeant analogues of cyclic AMP and cyclic GMP and NO-containing compounds of exocytosis in human neutrophils. Naunyn-Schmiedeberg's Arch Pharmacol 344: 396-402, 1991.

13. Seifert R, Serke S, Huhn D, Bessler W, Hauschildt S, Metzger J, Wiesmüller K-H and Jung G, Incomplete functional differentiation of HL-60 leukemic cells by synthetic lipopeptides. Partial inhibition by pertussis toxin of enhanced superoxide formation. EurJ Biochem 203: 143-151, 1992.

14. Seifert $R$ and Schultz $G$, Reversible activation of NADPH oxidase in membranes of HL-60 leukemic cells. Biochem Biophys Res Commun 146: 1296-1302, 1987.

15. Seifert R, Burde $R$ and Schultz G, Activation of NADPH oxidase by purine and pyrimidine nucleotides 
involves $\mathrm{G}$ proteins and is potentiated by chemotactic peptides. Biochem $J$ 259: 813-819, 1989.

16. Klinker JF, Höer A, Schwaner I, Offermanns $S$, Wenzel-Seifert $\mathbf{K}$ and Seifert R, Lipopeptides activate $\mathrm{G}_{\mathrm{i}}$-proteins in dibutyryl cAMP-differentiated HL-60 cells. Biochem J 296: 245-251, 1993.

17. Seifert R, Hagelüken A, Höer A, Höer D, Grünbaum L, Offermanns S, Schwaner I, Zingel V, Schunack W and Schultz G, The $H_{1}$ receptor agonist 2-(3chlorophenyl)histamine activates $\mathrm{G}_{\mathrm{i}}$-proteins in HL-60 cells through a mechanism that is independent of known histamine receptor subtypes. Mol Pharmacol 45: 578-586, 1994.

18. Rosenthal W, Koesling D, Rudolph U, Kleuss C, Pallast $M$, Yajima $M$ and Schultz $G$, Identification and characterization of the $35-\mathrm{kDa} \beta$ subunit of guaninenucleotide-binding proteins by an antiserum raised against transducin. Eur J Biochem 158: 255-263, 1986.

19. Offermanns S, Schultz G and Rosenthal W, Identification of receptor-activated $G$ proteins with photoreactive GTP analog, $\left[\alpha-{ }^{32} \mathrm{P}\right] \mathrm{GTP}$ azidoanilide. Methods Enzymol 195: 286-301, 1991.

20. Laugwitz K-L, Offermanns S, Spicher K and Schultz $\mathrm{G}, \mu$ and $\delta$ opioid receptors differentially couple to $\mathrm{G}$ protein subtypes in membranes of human neuroblastoma SH-SY5Y cells. Neuron 10: 233-242, 1993.

21. Lowry $\mathrm{OH}$, Rosebrough NJ, Farr $\mathrm{AL}$ and Randall RJ, Protein measurement with the Folin phenol reagent. $J$ Biol Chem 193: 265-275, 1951.

22. Walseth TF, Yuen PST and Moos MC Jr, Preparation of $\alpha{ }^{32} \mathrm{P}$-labeled nucleoside triphosphates, nicotinamide adenine dinucleotide, and cyclic nucleotides for use in determining adenylyl and guanylyl cyclases and cyclic nucleotide phosphodiesterase. Methods Enzymol 195: 29-44, 1991.

23. Cassel D and Pfeuffer T, Mechanism of cholera toxin action: covalent modification of the guanyl nucleotidebinding protein of the adenylate cyclase system. Proc Natl Acad Sci USA 75: 2669-2673, 1978.
24. Wenzel-Seifert $K$ and Seifert $R$, Nucleotide-, chemotactic peptide- and phorbol ester-induced exocytosis in HL-60 leukemic cells. Immunobiology 181: 298-316, 1990.

25. Gierschik $P$, Sidiropoulos D, Steisslinger $M$ and Jakobs $\mathrm{KH}, \mathrm{Na}^{+}$regulation of formyl peptide receptormediated signal transduction in HL 60 cells. Evidence that the cation prevents activation of the G-protein by unoccupied receptors. Eur J Pharmacol 172: 481-492, 1989.

26. Murphy PM, Eide B, Goldsmith P, Brann M, Gierschik $P$, Spiegel A and Malech HL, Detection of multiple forms of $\mathrm{G}_{\mathrm{i} \alpha}$ in HL60 cells. FEBS Lett 221: 81-86, 1987.

27. Stutchfield J and Cockcroft S, Correlation between secretion and phospholipase $\mathrm{D}$ activation in differentiated HL60 cells. Biochem $J$ 293: 649-655, 1993.

28. Seifert R, Höer A, Offermanns S, Buschauer A and Schunack $\mathrm{W}$, Histamine increases cytosolic $\mathrm{Ca}^{2+}$ in dibutyryl-cAMP-differentiated $\mathrm{HL}-60$ cells via $\mathrm{H}_{1^{-}}$ receptors and is an incomplete secretagogue, $\mathrm{Mol}$ Pharmacol 42: 227-234, 1992.

29. Ali H, Richardson R, Tomhave ED, Didsbury JR and Snyderman $R$, Differences in phosphorylation of formylpeptide and $\mathrm{C5a}$ chemoattractant receptors correlate with differences in desensitization, $J$ Biol Chem 268: 24247-24254, 1993.

30. Amatruda TT, Gerard NP, Gerard C and Simon MI, Specific interactions of chemoattractant factor receptors with G-proteins. I Biol Chem 268: 10139-10144, 1993.

31. Monk PN and Partridge LJ, Characterization of a complement-fragment-C5a-stimulated calcium-influx mechanism in U937 monocytic cells, Biochem $J$ 295: 679-684, 1993.

32. Pang I-H and Sternweis PC, Purification of unique $\alpha$ subunits of GTP-binding regulatory proteins (G proteins) by affinity chromatography with immobilized B $\gamma$ subunits, J Biol Chem 265: 18707-18712, 1990. 